\title{
CANADA AND HER RELATION TO THE EMPIRE
}

Having been requested to write something for this journal, it has occurred to me that it might be of interest to the reader and serve a useful purpose if I should undertake to point out what is a popular misconception regarding the position of Canada in the British Empire and to show how though apparently a dependency she is as independent as any self-governing state need be, and has a prestige in fact in the Empire from a constitutional point of view, on a par with that of any independent state with parliamentary powers as supreme within her own domain as any possessed by the Imperial Parliament within the United Kingdom.

English constitutional faw is the basis of the constitutional law of your Republic, and is the constitutional system in all the Colonies having representative government, so far as their interests and necessities require its introduction. Professor Dicey ${ }^{1}$ says of the preamble to The British North America Act, 1867, that:

"If preambles were intended to express the truth, for the word 'Kingdom' ought to 'have been substituted 'States'; since it is clear that the Constitution of the Dominion is modelled on that of the Union." "This is indeed denied, but in my judgment without adequate grounds, by competent Canadian critics. The difference between the institutions of the United States and of the Dominion are of course both considerable and noteworthy. But no one can study the provisions of the British North America Act, 1867, without seeing that its authors had the American Constitution constantly before their eyes, and that if Canada were an independent country it would be a Confederacy governed under a Constitution very similar to that of the United States. The Constitution is the law of the land; it cannot be changed either by the Dominion Parliament, or by the Provincial Parliaments; it can be altered only by the sovereign power of the British Parliament. Nor does this arise from the Dominion being a dependency."

What Professor Dicey says, as regards the British North America Act being the supreme law and above the authority of

${ }^{1}$ Law of the Constitution (3d Edition) pp. I55-I56.

(698) 
the Canadian Parliament, is true; but the British North America Act, while it fixes the limits within which legislation may take place, does not give to Canada, in every respect, a written constitution. It does not control its action in reference to the franchise; it does not determine the mode of constituting the courts; it does not create a legislature with delegated powers. It leaves the responsibility to the Ministers of the Crown, to Parliament, where it is left under the English system; and so, notwithstanding the limitations which have been imposed, it still remains true, that the Constitution of Canada is similar in principle to that of the United Kingdom.

Sir Francis Palgrave says:

"Every ancient Teutonic Monarchy was a federation; it is not a unit of which the smaller bodies politic therein contained are the portions, but they are the intigers, and the State is the - multiple which results from them."

And the same author further observes:

"It has been supposed the Kingdom has been reduced into a regular and gradual subordination of government, and that the various legal districts of which it is composed, arose from the divisions and subdivisions of the country. But this hypothesis, which tends greatly to perplex our history, cannot be supported by fact; and instead of viewing the constitution as a whole and then proceeding to its parts, we must examine it synthetically, and assume that the supreme authorities of the state were created by the concentration of the powers originally belonging to the members and corporations of which it is composed."

It was before this feature of the constitution had disappeared, that such measures as Magna Charta were carried. They were not the product of ordinary legislative authority, but compacts between the Sovereign and the Nation-fundamental principles of government that stood above the ordinary lawmaking power, and gave security to the rights and liberties of the people.

The people of Canada enjoy the same largeness of right, the same excellence of freedom that is enjoyed by the British freeman anywhere within the Empire. The constitutional law which deals with the internal relations, the institutions and func- 
tions of the State, is here as comprehensive as in the Motherland; that is, in their political conditions, and with reference to their powers, rights, duties, capacities, and incapacities, which are peculiar to political superiors, supreme and subordinate, they are controlled and regulated by the principles of English constitutional jurisprudence.

By the British North America Act, 1867, the Dominion was constituted by a union of four Provinces. The Provinces are to have the same boundaries after the union that they had before. What they had before you must go outside to discover, as the limits are not set out.

It has been maintained that the Imperial Parliament by this Act resumed for the moment from the Provinces all the powers which they possessed; that for the moment there was neither a federal union nor the Provinces which composed it; that all authority became actually vested in the Imperial Parliament, and that by the Act thereby emanated from this imperial authority the powers conferred on the new Dominion; that only such powers as may be inferred from this Act were derived by the parliaments of the Provinces and the Dominion.

This wholly erroneous view is founded upon a misconception of the nature of the supremacy claimed for the Imperial Parliament, and is incompatible with the rights of local selfgovernment conceded to a Colony of British settlers. The paramount authority of Parliament is not exclusive of the authority inherent in every Colony of Englishmen, and can only be employed for some very grave necessity of state. The Province has the inherent right of self-government, the legal title to the direction of its own affairs, but there is a dominium directum in the Imperial Parliament, which can only be used for those very grave purposes for which it is held in reserve, and any less serious purpose would make its use, not one of legal right, but of spoliation. Such a use in a Colony having a legislative assembly, as a Colony by settlement, would be subjecting it to a revolution; for its people derive their rights, neither from an Act of Parliament, nor from the favor of the Crown, but from the common law of England, and so, to supersede that inherent 
right, and to invoke the latent power of Parliament to its destruction, is revolution. Yet in a recent session of the Dominion Parliament agitators have made this dangerous proposal, that the Imperial Parliament be asked by the Dominion Parliament to so amend the British North America Act as to effect a curtailment of the power of one of the local Provincial legislatures.

When the Provinces asked to be federally united their request implied a continued autonomy. They agreed upon a basis of division of powers; what they should retain and with what the Dominion would be clothed. The Act which received the royal assent on the 29th of March, I867, came into effect the first of July following. There was ushered in the new state of things superseding the old; what powers the Provinces possess they retained out of the powers which they before held. Section Ninety-One of the British North America Act, I867, - enacts-to confer on the new legislative body the Parliament of Canada the power which it possesses; Section Ninety-Two declares and leaves to existing legislative bodies powers which they all along held.

This Act is a constitution providing for a system of federal government; it is a great act of state and cannot be subjected to the same rules of construction which you would apply to a contract or to a statute regulating the conduct of individuals. It refers you to the Constitution of the United Kingdom, not in detail, but in principle, to ascertain what the Constitution of Canada is. It refers you to a prior constitution of the Provinces to ascertain what their constitutions are. The Provinces were in existence with established parliamentary constitutions. They proposed to surrender a portion of their power in order to establish a federal union, and the plan by which that was to be accomplished is set out in Section Ninety-One of the Act.

All powers of government are under the constitutional law of England, reposed in the Crown, yet the Crown can in no case alone perform its functions. The King is sovereign, but not possessed of sovereign power. The sovereign power of the State is, in its legal side, in Parliament. A plentitude of power as well legislative as deliberative and executive, or power of 
jurisdiction in its full comprehension is in the High Court of Parliament. Solicitor-General Mitford, in the trial of Hardy, said:

"The power of the King, in name, is the state itself. All the powers of the state, legislative and executive, are nominally in him. Not really, because the King can make no law, but by the advice and with the assent of the Lords and Commons in Parliament. He can execute no law, but by the judges and other Ministers of Justice according to a formed and regular establishment. He really does nothing, but he nominally does everything. The consequence is, that he is to all intents and purposes the state; and in his name every act is done."

The Legislative Sovereign in England is the Crown in Parliament and the Executive Sovereign is the Crown in Council. The executive power of the Crown comprises what is called the royal prerogative, a term which $\mathrm{Mr}$. Dicey defines as "the discretionary authority of the executive" and he explains this to mean everything which the King or his servants can do without the authority of an Act of Parliament.

It is foreign to the purpose of this article to discuss the nature and functions of the Crown, but I might put it briefly, that the Crown in its Executive can act only upon the advice of its responsible Ministers. So an Act of the Crown is an act of the Ministers or the Executive department of the government.

While the Crown in Parliament enacts.through chosen rep-. resentatives of the people, we in the Colonies do not, as is popularly supposed, stand towards the Crown in a relation different from or inferior to that occupied by our fellow subjects in the United Kingdom. Royal prerogatives are part of the law of the land, and exist as part of the machinery of government.

In the United Kingdom there is no part of the law which may not be amended or repealed by the Imperial Parliament, and the same rule applies to every legislative assembly of every Province under the British North America Act, to every Royal prerogative falling within the field of its legislative jurisdiction.

"In 1859, upon the enactment of a new Canadian tariff, certain manufacturers of Sheffield moved the colonial secretary (the Duke of Newcastle) to protest against it. Whereupon his 
Grace wrote a despatch to the governor-general, dated August I3, I859, upon the subject. In reply, Mr. (after Sir Alexander) Galt, the Canadian finance minister, wrote a memorandum, which was transmitted to the colonial office by the governor-general, wherein he asserted it to be his duty 'distinctly to affirm the right of the Canadian legislature to adjust the taxation of the people in the way they deem best, even if it should unfortunately happen to meet the disapproval of the imperial ministry. Her Majesty cannot be advised to disallow such acts, unless her advisers are prepared to assume the administration of its inhabitants.' This position, he added, 'must be maintained by every Canadian administration.'

"The imperial government did not attempt to question the soundness of this position; and they have ever since evinced a disposition to acquiesce in the exercise, by the Canadian parliament, of the utmost freedom in the determination of their commercial policy, without regard to its application to or agreement with the ideas embodied in the legislation of the mother country, or advocated by the ministers of the Crown in Great Britain."2

Whenever the British parliamentary system of government has been established in the Colonies, it is the same sovereign whose name appears as in the United Kingdom. But in the Colony, in the executive capacity, he acts upon the advice of ministers chosen in the Colony. The law of the land here is enacted by the same sovereign but through a legislative body of representatives chosen by the people qualified under the law made by themselves.

The Parliament in a Colony is the same as the Parliament in the parent state. It is the supreme governing body in the State, and has the right to construct its own municipal polity and frame its own municipal law, and while the Imperial Parliament may have a supreme legislative jurisdiction, it cannot be exercised in a Colony where parliamentary government has been established in any manner so as to interfere with, subvert or abridge the rights of those who have acquired the right to govern themselves. The Canadian Parliament and the Provin-

\footnotetext{
${ }^{2}$ Alphaeus Todd-Parliamentary Government in the Colonies, pp. I8I-182.
} 
cial legislatures are within their several jurisdictions as independent and powerful to enact laws for Canada or the Provinces as the Imperial Parliament is supreme, powerful and independent to make laws for the United Kingdom. In a Colony possessed of representative government the people are by the common law upon the same footing as the people of the United Kingdom.

The Dominion of Canada had no existence prior to 1867 . The Provinces which were united into one Dominion had. They were possessed of parliamentary institutions. They had systems of government similar in principle to that of the United Kingdom, and the Sovereign was an integral part of every legislature. By the Quebec Act of $\mathbf{1 7 7 4}$, the ordinances which were to be enacted by the Governor and his Council, required the Royal approval, and so they were made the acts of the Crown. Under the Constitutional Act of I79I, section 2, it was enacted that:

"In each of the said provinces respectively, His Majesty, His Heirs and Successors shall have power during the continuance of this Act, by and with the advice and consent of the Legislative Council and Legislative Assembly of such provinces respectively, to make laws for the peace, welfare and good government thereof, and laws not being repugnant to this act, etc."

And by Section Three of the Union Act of 1840 , by which Upper Canada and Lower Canada were legislatively united, it is provided that all such laws being passed by the said Legislative Council and Legislative Assembly and assented to by Her Majesty or assented to in Her Majesty's name, by the Governor of the Province of Canada, shall be valid and binding to all intents and purposes within the Province of Canada. So that the executive power of and over Quebec, of and over the two Canada, of and over United Canada, down to the first of July, I867, was in Her Majesty's Royal predecessors and in Her Majesty. The Provinces that expressed a desire to be federally united were, at the union, denuded of a portion of the powers which they previously possessed, but their original constitutions were not destroyed. Their government continued similar in principle to that of the United Kingdom. They were not made 
so by the British North America Act; they were so before, and the Act did not in this respect change their constitutions. What was aimed at by the promoters of the Act of 1867 is carefully stated in the preamble to the Act. It was said by Lord Carnarvon that the Act was a treaty. It evidences a treaty. It is the legal expression of a treaty between parties, and clothes their agreement, as to the terms of union, with legal sanction. It says that the Provinces had expressed their desire to be united and what they wanted the union to be; not a union brought about by the destruction of the parties seeking it, but by their continued existence.

In order that a federal union may exist there must be political communities, having an autonomy to be united. The desire which the Provinces expressed, the desire to which effect was given was to make a new state with a government similar - in principle to that of the United Kingdom. The new government was to be parliamentary; the executive authority was to be in the Crown; the powers of the Crown were to find expression through instruments, and with formalities similar to those employed in the United Kingdom. The legislative authority is constituted, the executive authority is declared. That is all; the form of its life, the character of its spirit, must be sought elsewhere. It is to be similar in principle to the constitution of the United Kingdom. How it is to be made similar in principle, what will make it so, must be ascertained outside of this Act. The same irresponsibility of the Sovereign, the same responsibility of Ministers, who are to stand in the same relation to the House of Commons and having a tenure of office subject to similar rules and usages, and the same relation must exist between power and responsibility. This wish and intention as to the form of government, is not expressed as to the Provinces, but of the Union alone. The Union was to be a union under the Crown, and the Sovereign is declared to be a part of the government. The legislature of the new government must be constituted because it did not previously exist. But as to the executive government therein, that is, in the Dominion, it has only to be declared, because it is already constituted; it is in the 
Crown, as a part of the government of the Provinces. A part is withdrawn, not from the Sovereign, but from the Sovereign's advisers in the Colonies to be united, to be exercised under the advice of the Queen's or King's privy Council for Canada. The Sovereign never acts alone. The executive government in every part of the Empire, where parliamentary government is established is in the King in Council. The authority of the Sovereign prevails in every part of the Empire; the prerogatives of the Crown are in every part of it the same, but the Sovereign is not everywhere counselled by the same persons. There are legal boundaries which limit the authority of his different class of advisers, and which they are under constitutional usage bound to respect. Within the different sections of the Dominion the authority of each is conclusive; but when he reaches the boundary of any one part, he parts company with one set of counsellors; and another set are provided by the constitution to aid him by their advice. Where the authority of one group ends, that of another group begins and so a controversy in respect to the validity of his action can seldom relate to his authority, but must have reference to the authority of those who in the specific case are entitled to aid him by their counsels.

With regard to the domestic affairs of a Colony having parliamentary institutions, there can be no question ordinarily as to whom the right constitutionally belongs of advising the Sovereign.

Our right of self-government might possibly be involved in a conflict of imperial and domestic authority; the Ministers of the Crown here are the proper constitutional advisors of the Crown in respect to everything which locally concerns us, and the only danger is from the exercise of the Imperial Executive function in its diplomatic jurisdiction. But it is well understood by constitutional usage that imperial supremacy must not invade the sphere of domestic authority.

Moose Jaw, Canada.

Walter Mills. 